\title{
ANALYSIS OF RIDE COMFORT IN SELECTED TYPES OF RAIL VEHICLES
}

\section{Analiza komfortu jazdy pasażera wybranych typów pojazdów szynowych}

\begin{abstract}
The subject of the article is the analysis of ride comfort for a passenger of selected types of rail vehicles on the basis of the main factor determining its level - mechanical vibrations. The research was based on measurements of vibration accelerations and the RMS values in one-third octave bands which were calculated from the measured accelerations. The tested objects were four types of rail vehicles. This article presents the results of the analysis carried out for each vehicle, using two methods of assessing the impact of vibrations on the human body.
\end{abstract}

Keywords: ride comfort, rail vehicles, vibrations

Streszczenie: Przedmiotem artykułu jest analiza komfortu jazdy pasażera wybranych typów pojazdów szynowych na podstawie podstawowego czynnika determinujacego jego poziom - drgań mechanicznych. Badania zostały oparte na pomiarach przyspieszeń drgań oraz obliczonych na ich podstawie wartości skutecznych w pasmach tercjowych. Obiektami badanymi byty cztery typy pojazdów szynowych. Wniniejszym artykule zamieszczono wyniki analizy przeprowadzonej dla każdego z pojazdów, z wykorzystaniem dwóch metod oceny wpływu drgań na organizm człowieka.

Słowa kluczowe: komfort jazdy, pojazdy szynowe, drgania 


\section{Introduction}

With the development of transport, the expectations of consumers of transport services also increase. Passengers requirements concern the increasing availability of means of transport in time, the travel time itself and the improvement of travel conditions. Thus, ride comfort becomes a factor that is important in the context of the competitiveness between different modes of transport [3] and the level of comfort can determine customer choices in this respect. Providing a positive experience of comfort should not be result only from the desire to meet the growing demands of passengers. The appropriate level of ride comfort has an impact on the health of passengers and their safety, especially when traveling over longer distances. This paper is aimed at identifying the most important factors determining ride comfort and analyzing its level in selected rail vehicles

\section{Ride comfort in means of transport}

Ride comfort is a complex term influenced by many factors. This term is used to describe the psychophysical satisfaction of a passenger in a vehicle. First of all, passenger ride comfort means all external conditions that ensure a sense of safety, but also satisfaction during the journey $[17,18]$. The presence of any negative stimuli may contribute to a significant reduction in the perceived level of comfort. Long lasting or intense inconveniences experienced by passengers result in the opposite state of discomfort.

Passenger sensations and feelings related to ride comfort are determined by a number of factors related to the environment in which the passenger travels and its individual characteristics $[6,8,18]$. The factors influencing the level of comfort include such elements of space as the layout of the passenger compartment, the amount of leg room and the distance between the seats. This group of factors also contains the parameters of the seat allowing the passenger to take an ergonomic position. Therefore, the shape of the seat, its profile and height, the layout of armrests and headrests, and the ability of adjusting the angle of the backrest are important. Another factor related to space is the color scheme of the interior of the vehicle [19]. It is recommended to use neutral and subdued colors inside the passenger compartments so as to maintain right contrast, reduce reflection and be able to provide proper lighting [1]. In the case of space-time factors that may reduce the perceived comfort level, number of passengers and cleanliness of the vehicle as well as the travel time and possible delays should also be mentioned [2, 8, 17].

The level of ride comfort largely depends on such environmental factors as noise, vibrations, lighting, air temperature, its humidity and circulation, and time of exposure to particular stimuli. Therefore, it is important to maintain right microclimatic conditions and ensure thermal comfort through efficient ventilation and air conditioning. Under optimal thermal conditions, the passenger feels the temperature evenly, and no part of his body is excessively cooled or overheated [5]. In the literature on the subject, it is possible to find 
guidelines for lighting that provides positive feelings of visual comfort, with the most important factors being the intensity and uniformity of lighting and its color temperature [1, 18]. In the case of acoustic comfort, it is important to limit any undesirable, unpleasant, annoying or even harmful sounds. The noise parameters that are of greatest importance in ride comfort research are the intensity and frequency of sound as well as the presence of inaudible noise components. The nature of acoustic stimuli is also important, including whether the passenger is exposed to continuous or impulsive noise, and how long he or she is exposed to it. In the group of environmental factors that determine the feeling of comfort, vibrations are the most important and most frequently studied factor [4, 8-13, 17, 18]. During travel, the rail vehicle performs translational and vibrating movements. Vibrations affecting a passenger may result in functional or physiological effects depending on the time of their occurrence $[14,15]$. The most important vibration parameters taken into account in the analysis of their impact on ride comfort are the acceleration amplitude and their frequency $[8,18]$. Sensations related to vibration comfort also depend on the place where the vibrations are applied to the human body and the direction of their propagation.

In addition to the factors that determine the passenger's environment, it is also necessary to mention those that depend solely on the individual characteristics of a person. The negative or positive feelings related to ride comfort may be influenced by weight, height, body composition, physical and mental condition, health, or the gender and age of the passenger. The perception of comfort may differ from one passenger to another due to body posture, the individual dynamic response of the body and even the personal expectations and mental attitude of the passenger.

\section{Methods of ride comfort evaluation}

The analysis of ride comfort in a rail vehicle can be based on various indicators determined on the basis of physical quantities that characterize the environment. In this study, the research is focused on the main factor determining the feelings related to comfort, i.e. mechanical vibrations. Two methods were used for the analysis of ride comfort due to vibrations. The first was the spectral method according to the recommendations of the standard ISO 2631-1: 1985 [7], which allows the assessment of the influence of general vibrations on human body. The quantity describing the vibrations, which this method is based on, are the RMS accelerations in one-third octave bands, measured in three directions. The second method of assessing the impact of vibrations on the sensations related to comfort was the weighted method in accordance with the 1997 edition of the same standard, where recommendations for determining the synthetic comfort index were introduced and this index is also calculated on the basis of the RMS value. 


\subsection{Spectral method}

The analysis of the ride comfort based on the spectral method requires measurements of vibration accelerations in three directions: transverse, longitudinal and vertical. Based on the experimental results of accelerations in the time domain, their RMS values should be determined in one-third octave bands with centre frequencies ranging from $0.8 \mathrm{~Hz}$ to $80 \mathrm{~Hz}$. Then the RMS values are compared with the of reduced comfort boundary, the fatiguedecreased proficiency boundary and the exposure limit. In the ISO 2631-1:1985 standard, the limits are defined separately for longitudinal and transverse vibrations, and for vertical vibrations.
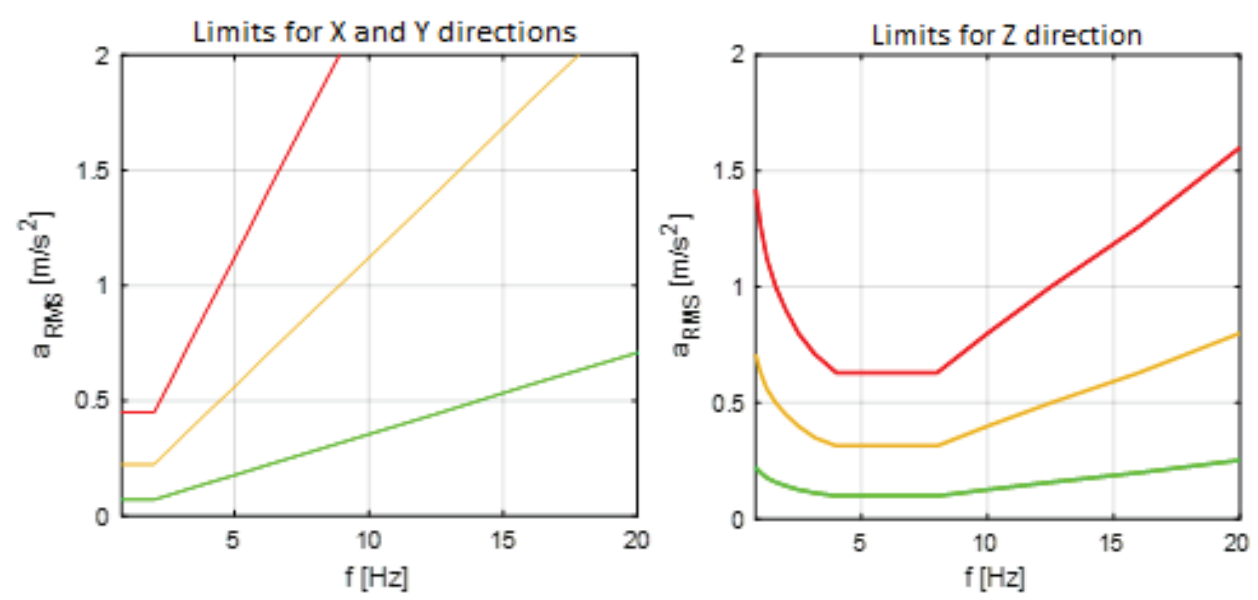

Fig. 1. Reduced comfort boundary (green line), the fatigue-decreased proficiency boundary (orange line) and the exposure limit (red line) in accordance with ISO 2631-1: 1985 [7]

\subsection{Weighted method}

In the weighted method, the ride comfort index is determined and is expressed as total weighted RMS acceleration according to the ISO 2631-1: 1997 standard [7] As in the spectral method, the analysis of vibrational comfort is based on the RMS values of vibration accelerations in one-third octave bands. This values should be averaged using the weights defined in the ISO standard. The weighting function $W_{d}(f)$ is used for vibrations in the longitudinal and transverse directions, and the weighting function $W_{k}(f)$ for vibrations in the vertical direction. 


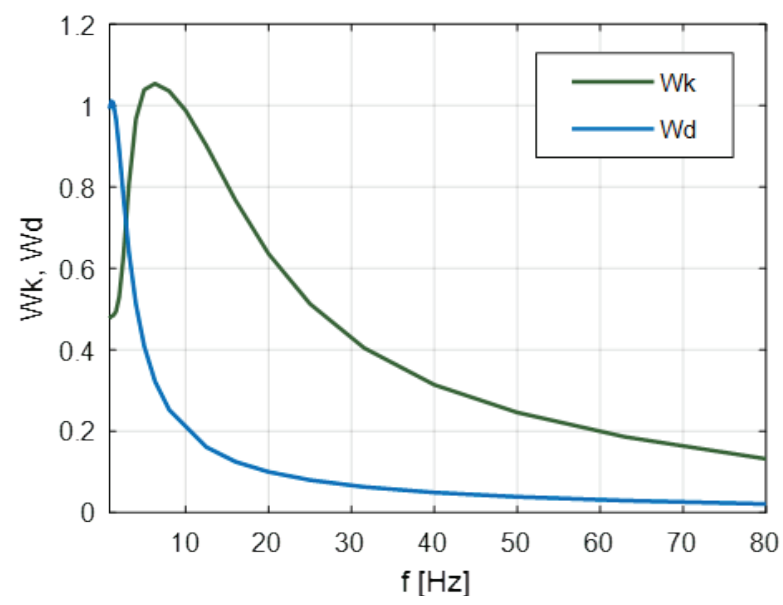

Fig. 2. Weighting functions $\mathrm{W}_{\mathrm{k}}$ and $\mathrm{W}_{\mathrm{d}}$ used in the weighted method according to the 2631-1: 1997 standard [7]

To calculate the average weighted RMS values of the acceleration components, the following formulas were used:

$$
a_{x, r m s-w}=\sqrt{\sum_{i=1}^{n}\left[W_{d}\left(f_{i}\right) a_{x, r m s}\left(f_{i}\right)\right]^{2}}
$$

where:

$\mathrm{W}_{\mathrm{d}}\left(\mathrm{f}_{\mathrm{i}}\right)$ - value of the weighting function in the $i$-th third octave band, $a_{\mathrm{x}, \text { rms }}\left(\mathrm{f}_{\mathrm{i}}\right)-$ RMS value in the $x$ direction in the $i$-th $1 / 3$ octave band, $a_{\mathrm{x}, \mathrm{rms}-\mathrm{w}}-$ average weighted RMS value for the $x$ direction,

$$
a_{y, r m s-w}=\sqrt{\sum_{i=1}^{n}\left[W_{d}\left(f_{i}\right) a_{y, r m s}\left(f_{i}\right)\right]^{2}}
$$

where:

$\mathrm{W}_{\mathrm{d}}\left(\mathrm{f}_{\mathrm{i}}\right)$ - value of the weighting function in the $i$-th third octave band,

$a_{\mathrm{y}, \text { rms }}\left(\mathrm{f}_{\mathrm{i}}\right)-\mathrm{RMS}$ value in the $y$ direction in the $i$-th $1 / 3$ octave band,

$a_{\mathrm{y}, \text { rms-w }}-$ average weighted RMS value for the $y$ direction,

$$
a_{z, r m s-w a \dot{z}}=\sqrt{\sum_{i=1}^{n}\left[W_{k}\left(f_{i}\right) a_{z, r m s}\left(f_{i}\right)\right]^{2}}
$$

where:

$\mathrm{W}_{\mathrm{k}}\left(\mathrm{f}_{\mathrm{i}}\right)$ - value of the weighting function in the $\mathrm{i}$ third octave band,

$a_{\mathrm{z}, \mathrm{rms}}\left(\mathrm{f}_{\mathrm{i}}\right)-\mathrm{RMS}$ value in the $z$ direction in the $i$-th $1 / 3$ octave band,

$a_{\mathrm{z} \text {, rms-w }}-$ average weighted RMS value for the $z$ direction. 
Based on the weighted RMS values of the acceleration components, the ride comfort index is determined with formula (4)

$$
a_{r m s-w}=\sqrt{a_{x, r m s-w}^{2}+a_{y, r m s-w}^{2}+a_{z, r m s-w}^{2}}
$$

where:

$a_{\text {rms-w }}$ - comfort index expressed as the total weighted RMS acceleration.

The calculated comfort index needs to be compared with the descriptive comfort scale given in table 1 .

Table 1

The comfort scale according to the ISO 2631-1: 1997 standard [7]

\begin{tabular}{|l|l|}
\hline \multicolumn{1}{|c|}{ arms_w } & \multicolumn{1}{c|}{ Comfort level } \\
\hline below 0.315 & comfortable \\
\hline from 0.315 to 0.630 & slightly uncomfortable \\
\hline from 0.500 to 1.000 & quite uncomfortable \\
\hline from 0.800 to 1.600 & uncomfortable \\
\hline from 1.250 to 2.500 & very uncomfortable \\
\hline above 2.000 & extremely uncomfortable \\
\hline
\end{tabular}

\section{Ride comfort in rail vehicles - an experimental study}

\subsection{Acceleration measurements}

The analysis of ride comfort concerned four types of rail vehicles: the $120 \mathrm{Na}$ "Swing" tram, 27WE "Elf" electric multiple unit, Siemens Inspiro metro train and passenger train compiled of carriages Z1B and the Pesa Gama locomotive. In each of these vehicles, one measurement point was selected in which vibration accelerations were recorded simultaneously in three directions. All measurements were carried out during a typical ride with passengers, taking into account such conditions as braking, steady ride, and crossing junctions. For the measurements of vibration accelerations, measuring equipment in the form of a triaxial seat accelerometer and a transducer card were used. The measurements were recorded on a laptop with LabView software. As a result of the experiment, time samples of vibration acceleration were obtained. An example of one of the measurement results is shown in Figure 3 for a measurement recorded in a metro train. 

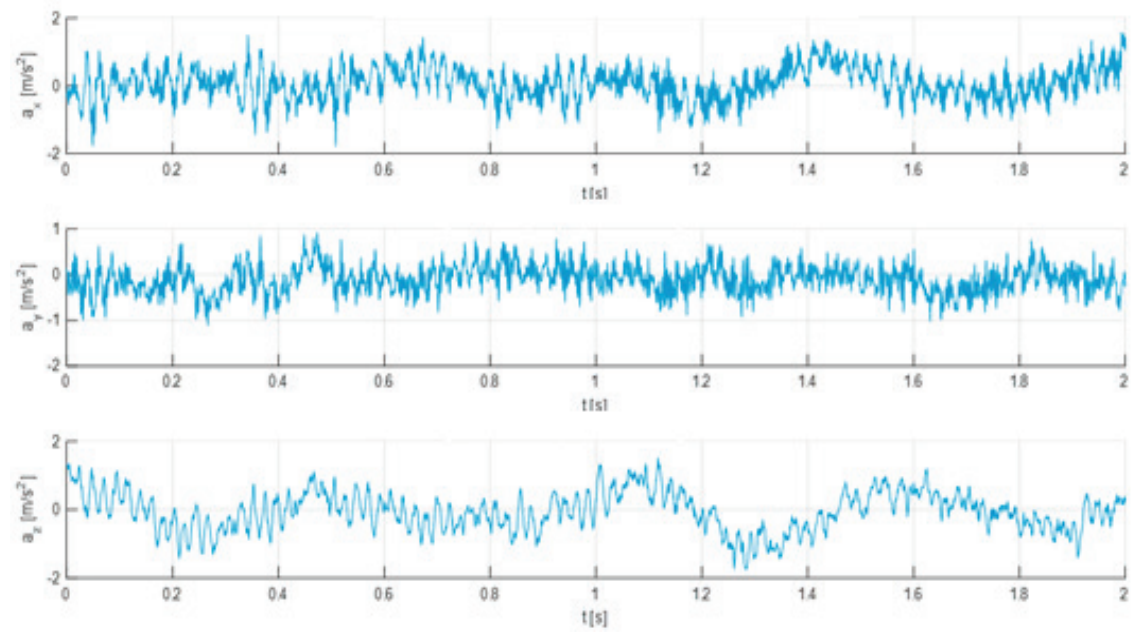

Fig. 3. Vibration accelerations recorded in the selected measurement on the Siemens Inspiro metro train

\subsection{Analysis of ride comfort with the spectral method}

On the basis of selected results of experimental tests, the RMS values of vibration accelerations in one-third octave bands were calculated for each of the tested types of rail vehicles. Figures 4-7 show the RMS results along with the comfort boundaries compliant with the ISO 2631-1: 1985 standard [7].

The results obtained for the metro train presented in the figure 4 show that the reduced comfort boundary was exceeded only in the case of low-frequency vibrations acting in the longitudinal direction. The RMS results for lateral vibrations are within the comfort limit. Therefore, it can be concluded that vibrations in this direction did not cause negative feelings related to the vibrational comfort. As with the vibrations in the longitudinal direction, the RMS of vertical vibrations exceeded the reduced comfort boundary in the low frequency bands. At the frequencies of $16 \mathrm{~Hz}$ and $40 \mathrm{~Hz}$, another increase in the RMS vertical vibrations is noticeable, but these values cannot be considered as lowering the level of comfort felt by a metro train passenger - the comfort limit has not been exceeded. 
a)

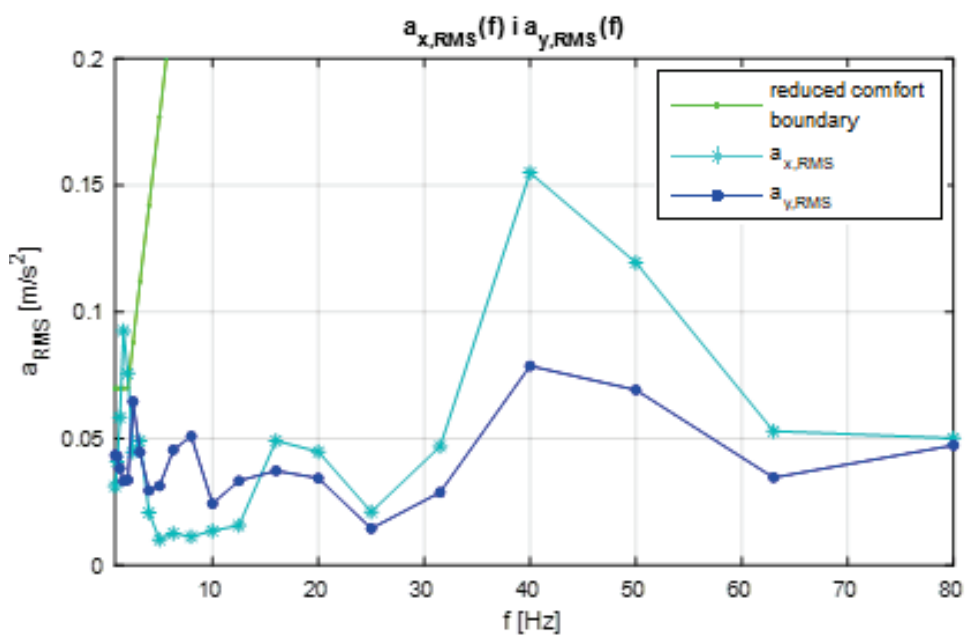

b)

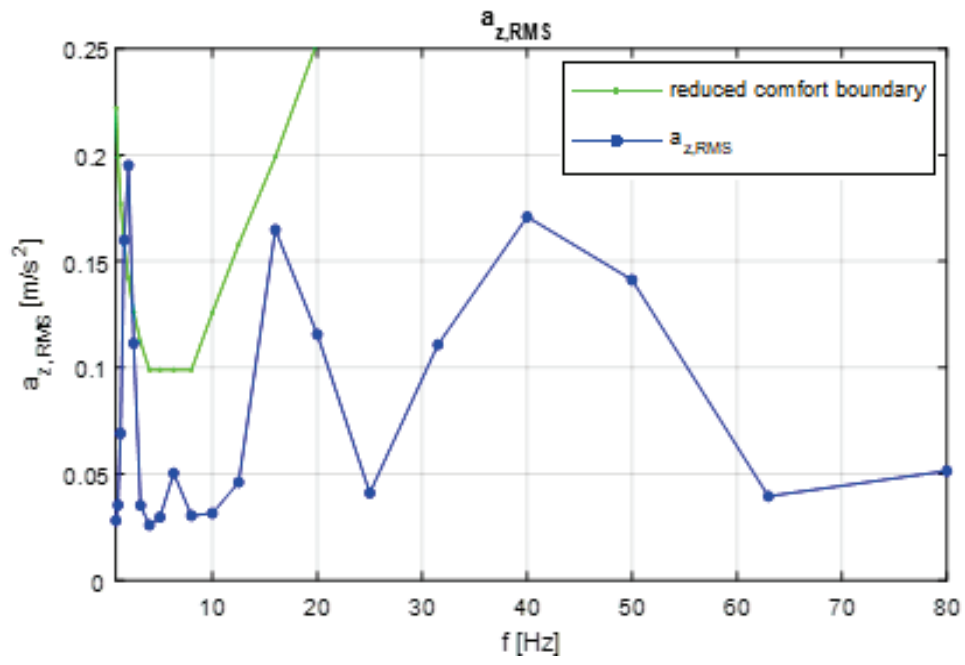

Fig. 4. RMS values of vibration accelerations measured in the Siemens Inspiro metro train, in the longitudinal and transverse directions (a) and the vertical direction (b), compared with the reduced comfort boundary

When analyzing the graphs of the RMS acceleration values for the $120 \mathrm{Na}$ Swing tram (fig. 5), it can be noticed that the reduced comfort boundary was exceeded in the case of vibrations affecting the passenger in each of the three directions. Most of the cases of exceeding this limit were observed for vibrations of low frequencies. Particular attention should be paid to the RMS values of vertical vibrations. For low frequencies in the $1.6-2 \mathrm{~Hz}$ range, not only the comfort limit is exceeded, but also the fatigue-decreased proficiency boundary. Unlike other directions of vibration propagation, the comfort limit was exceeded 
in the case of vertical vibrations also for higher frequencies. Therefore, vertical vibrations have the greatest impact on the negative feelings related to ride comfort.

a)

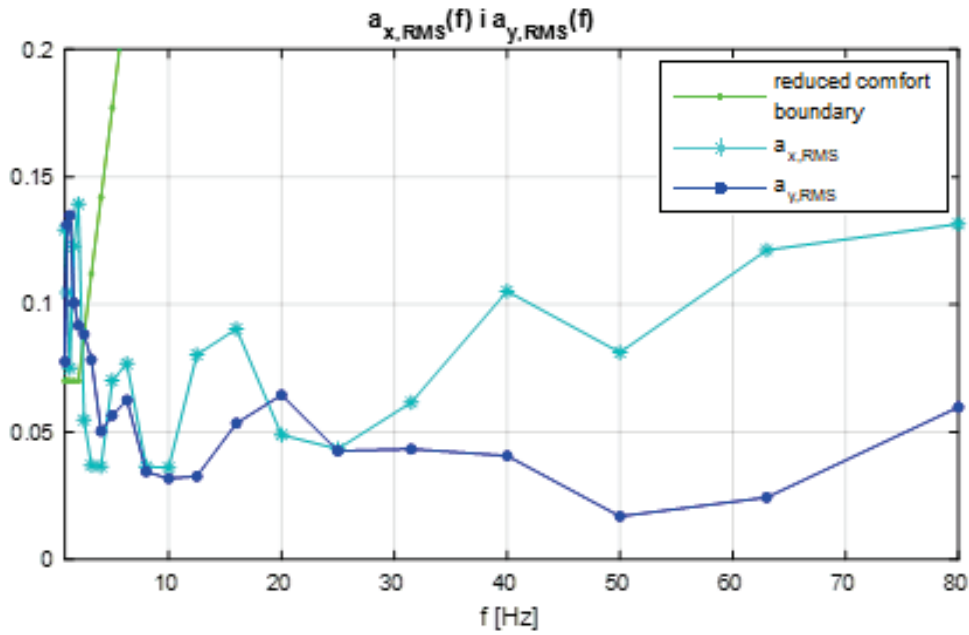

b)

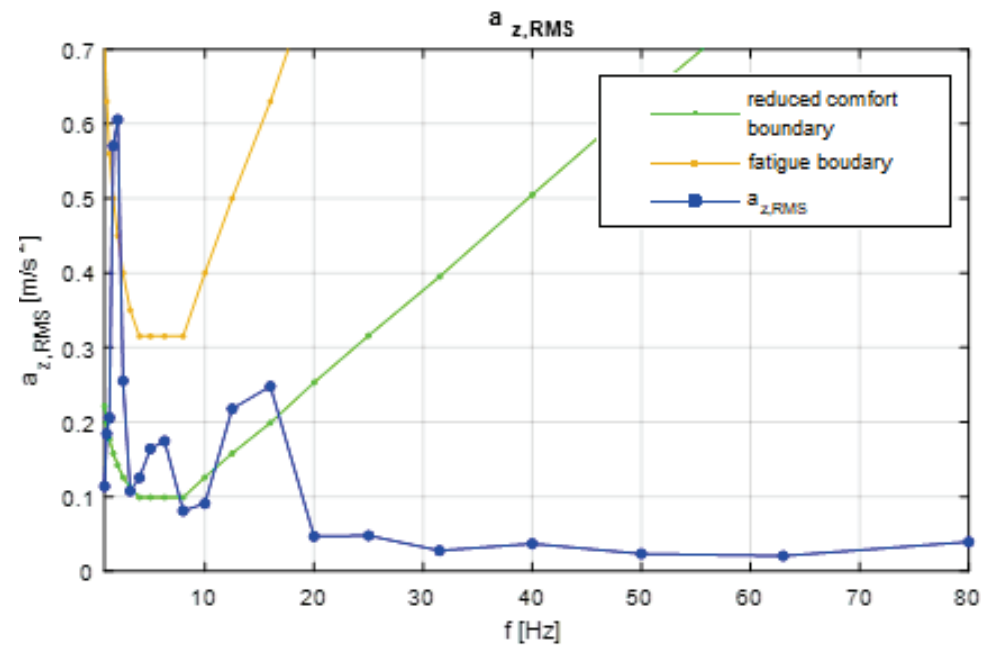

Fig. 5. RMS values of vibration accelerations measured in the tram, in the longitudinal and transverse directions (a) and the vertical direction (b), compared with the reduced comfort and fatiguedecreased proficiency boundaries

In the case of the RMS results for the 27WE "Elf" vehicle (fig. 6), it is noticeable that the comfort limit is slightly exceeded only due to the vibrations affecting the passenger in the lateral direction. The limit was exceeded for frequencies below $2 \mathrm{~Hz}$. The effective values of the acceleration of longitudinal and vertical vibrations were so small that it cannot be considered that they had a negative impact on the experience of ride comfort. Due to the 
slightly exceeding the comfort limit by transverse vibrations only, it can be considered that the journey of the $27 \mathrm{WE}$ "Elf" vehicle is quite comfortable.

a)

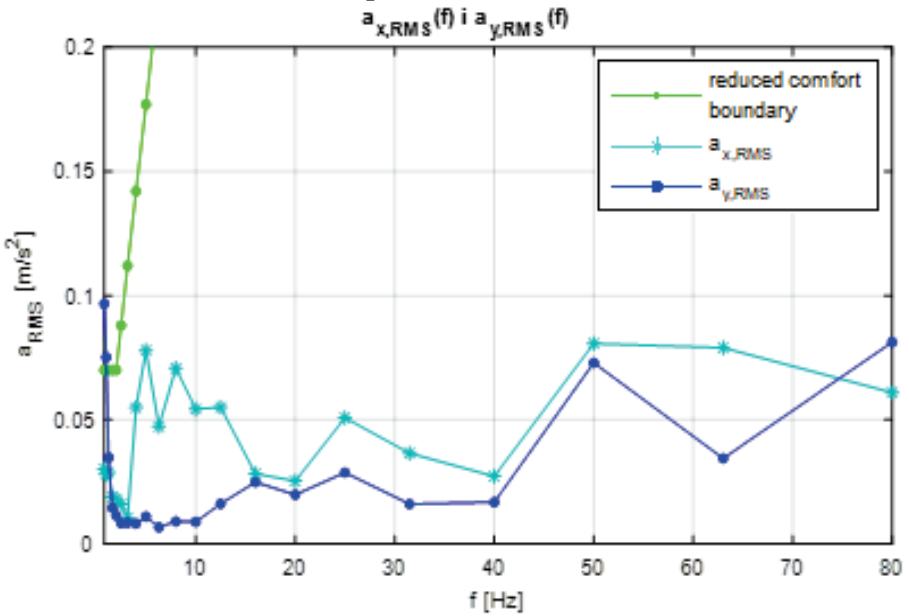

b)

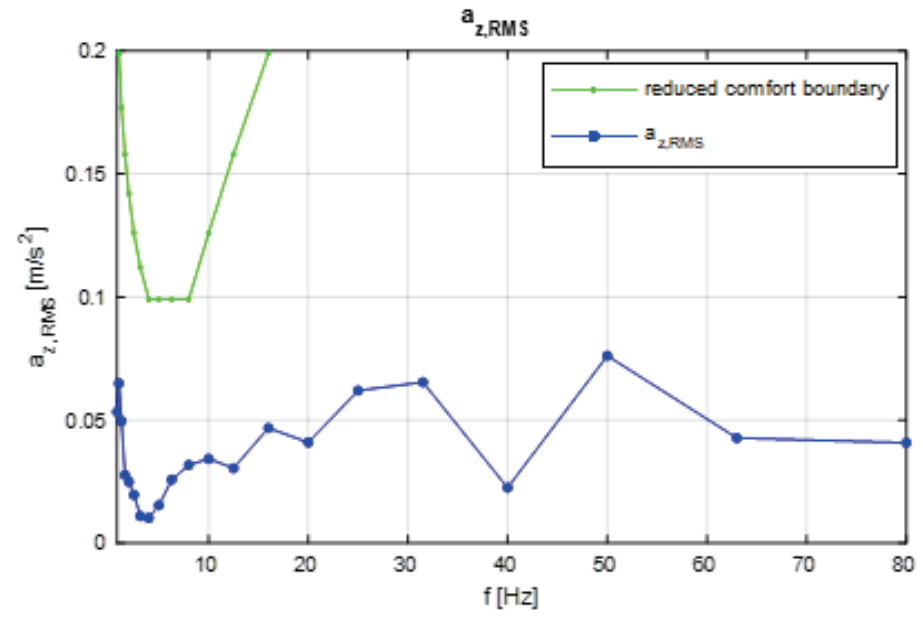

Fig. 6. RMS values of vibration accelerations measured in EMU 27WE "Elf", in the longitudinal and transverse directions (a) and the vertical direction (b), compared with the reduced comfort boundary

According to the results presented in fig. 7, the RMS values of longitudinal and transverse vibrations in the tested passenger train do not exceed the comfort limit determined by the reduced comfort boundary. For the center frequency of the band equal to $80 \mathrm{~Hz}$, a significant increase in the RMS values is noticeable. This increase, however, did not contribute to a reduction in the level of comfort perceived by the passenger, as the RMS values did not exceed the comfort limits. Part $b$ of fig. 7 shows the results for vertical vibrations. As with the results for the previous vehicles, the comfort limit was exceeded by 
low-frequency vibrations. When analyzing the graph, it can be noticed that for the remaining frequencies the obtained RMS values are relatively small, so they do not adversely affect the vibrational comfort.

a)

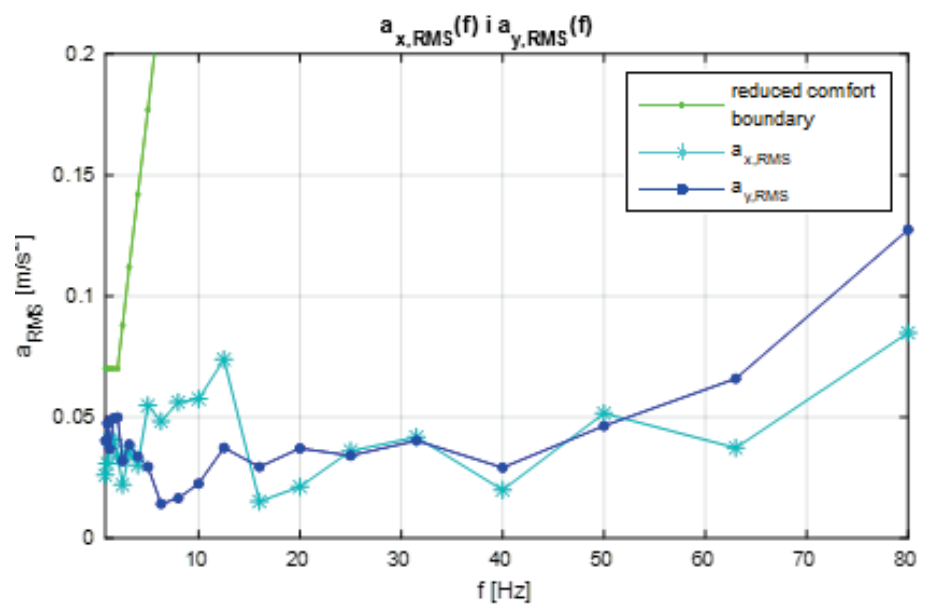

b)

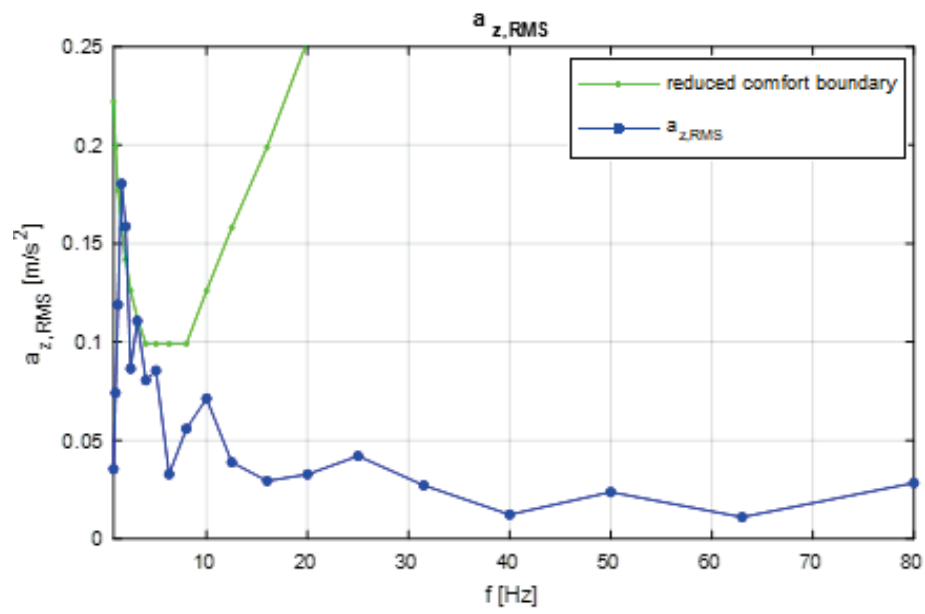

Fig. 7. RMS values of vibrations measured in a passenger train, in the longitudinal and transverse directions (a) and vibrations in the vertical direction (b) compared with the reduced comfort boundary

\subsection{Assessment of ride comfort level with the weighted method}

In the second stage of the analysis of the passenger's ride comfort in rail vehicles, the weighted method was used. On the basis of the previously determined RMS values and with the use of formulas (1)-(4) and the weighting functions, the ride comfort indicators were 
calculated in accordance with the standard ISO 2631-1: 1997 [7]. The results for the weighted RMS values of acceleration components in $x, y, z$ directions and the ride comfort index along with the corresponding comfort level are presented in table 2.

Table 2

\section{Weighted RMS values of acceleration components and ride comfort index for the tested rail vehicles}

\begin{tabular}{|c|c|c|c|c|c|}
\hline Rail vehicle & $\mathrm{a}_{\mathrm{x}_{-} \mathrm{RMSw}}$ & $\mathrm{a}_{\mathrm{y}_{-} \mathrm{RMSw}}$ & $\mathrm{a}_{\mathrm{z}_{-} \mathrm{RMSw}}$ & $\mathrm{a}_{\mathrm{RMSw}}$ & comfort level \\
\hline metro & 0.146 & 0.107 & 0.246 & 0.305 & comfortable \\
\hline tram & 0.260 & 0.259 & 0.638 & 0.736 & $\begin{array}{c}\text { quite } \\
\text { uncomfortable }\end{array}$ \\
\hline EMU & 0.077 & 0.129 & 0.105 & 0.183 & comfortable \\
\hline $\begin{array}{c}\text { Passenger } \\
\text { train }\end{array}$ & $0, .90$ & 0.107 & 0.239 & 0.277 & comfortable \\
\hline
\end{tabular}

Comparing the value of the comfort index obtained for the metro train with the comfort scale, it can be concluded that the vibrations did not adversely affect the feeling of the comfort level. Similar results were observed for the passenger train, where the comfort index reached a slightly lower value. In the case of the Elf vehicle, the calculated index was the lowest, therefore, ride in this vehicle can be considered the most comfortable among all the analyzed means of transport. The highest result of the comfort index was recorded for the Swing tram. The value of the index ranges from 0.5 to $0.1 \mathrm{~m} / \mathrm{s}^{2}$. According to the scale, travelling in this vehicle should be considered quite uncomfortable. Importantly, the value of the index was close to reaching the next level on the scale, where ride is defined as uncomfortable.

\section{Conclusions}

Two methods were used in the study of the ride comfort of a rail vehicle passenger, based on measurements of the acceleration of mechanical vibrations. The analysis of these accelerations using the spectral method and the weighted method made it possible to assess the impact of vibrations in the tested vehicles on the sensations related to comfort. The most important conclusions from the conducted research are presented below:

- the greatest ride comfort is ensured by traveling in a Elf vehicle (the lowest value of the comfort index), while the worst feelings related to vibrational comfort are experienced by the passengers of the $120 \mathrm{Na}$ "Swing" tram (high value of the comfort index),

- only in the case of a tram, the RMS acceleration values exceeded the reduced comfort boundary in all directions of vibrations, additionally, the RMS 
accelerations of vertical vibrations of low frequencies also exceeded the fatiguedecreased proficiency boundary,

- most of the cases of exceeding the reduced comfort boundary took place for vibrations acting in the vertical direction, they were vibrations of low frequencies.

The results of experimental studies have shown that low-frequency vibrations contribute to the greatest reduction in the feeling of comfort. Vibrations affecting the passenger in this way should be given special attention due to the possibility of resonance phenomena for vibrations of internal organs. Due to the complexity of the issue of ride comfort and differences in the perception of stimuli affecting humans, it is advisable to expand the scope of research. The analysis of ride comfort can therefore be extended to include acoustic, thermal and visual comfort as well as questionnaire surveys determining the subjective feeling of comfort.

\section{References}

1. Chrzanowicz M.: Wymagania normalizacyjne dotyczące oświetlenia elektrycznego pojazdów szynowych w systemach transportu publicznego (PN-EN 13272: 2012) oraz analiza wybranych systemów oświetleniowych. Logistyka nr 4, CD 2/2014.

2. Ciastoń-Ciulkin A.: Analiza poziomu komfortu podróży w pociągach aglomeracyjnych na trasie Kraków Lotnisko/Airport-Wieliczka Rynek Kopalnia. Transport Miejski i Regionalny, nr 6/2017.

3. Dyr T.: Konkurencyjność transportu kolejowego na rynku regionalnych przewozów pasażerskich. TTS Technika Transportu Szynowego, nr 1-2/2004.

4. Förstberg J.: Ride comfort and motion sickness in tilting trains. Doctoral Thesis, Instituten för farkosttenknik, Stokholm 2000.

5. Gużda A., Szmolke N.: Przykłady rozkładu parametrów powietrza w autobusie komunikacji miejskiej. Autobusy: technika, eksploatacja, systemy transportowe, nr $6 / 2016$.

6. Gołębiowski P., Żak J., Jacyna-Gołda I.: Approach to the Proecological Distribution of the Traffic Flow on the Transport Network from the Point of View of Carbon Dioxide. Sustainability 12.17 (2020): 6936.

7. ISO 2631-1: Mechanical Vibration and Shock. Evaluation of human exposure wholebody vibration. Part 1: General Requirements. International Organization for Standardization, 1985 and 1997.

8. Kardas-Cinal E.: Bezpieczeństwo i komfort jazdy pojazdu szynowego z uwzględnieniem losowych nierówności geometrycznych toru, nr 94, Oficyna Wydawnicza Politechniki Warszawskiej, Warszawa 2013.

9. Kardas-Cinal E.: Metody oceny komfortu wibracyjnego w środkach transportu. Prace Naukowe Politechniki Warszawskiej, Transport, z. 112, 2016. 
10. Kardas-Cinal E.: Statistical analysis of dynamical quantities relate to running safety and ride comfort of a railway vehicle. Zeszyty Naukowe. Transport - Politechnika Śląska, t. 106, 2020.

11. Krakasis K., Skarlatos D., Zakinthios T.: A factorial analysis for the determination optimal train speed with desired ride comfort. Tilemachos Applied Acoustics, Vol. 66(10), 2005.

12. Król S.: Przegląd metod oceny wibracyjnego komfortu jazdy w pojazdach szynowych. Transport Miejski i Regionalny, nr 3/2009.

13. Król S., Szczygieł J.: Badania poziomu komfortu wibracyjnego w wybranych tramwajach. Problemy eksploatacji, nr 2/2009.

14. Nader M.: Drgania i hałas w transporcie: wybrane zagadnienia. Oficyna Wydawnicza Politechniki Warszawskiej, Warszawa 2016.

15. Nader M., Ilczuk P., Korzeb J.: Oddziaływanie drgań na kierowcę pojazdu podczas niestandardowej eksploatacji. Logistyka 4, 2015.

16. PN-EN 13272-1:2020-03 Kolejnictwo - Oświetlenie elektryczne pojazdów szynowych w systemach transportu publicznego - Część 1: Kolej, PKN, 2020.

17. Rybicka I., Tarkowski S.: Metody oceny poziomu komfortu dynamicznego w transporcie pasażerskim, Autobusy: technika, eksploatacja, systemy transportowe, nr $12 / 2016$.

18. Šipic P.: Komfort jazdy w pasażerskim transporcie szynowym, Technika Transportu Szynowego, nr 7-8/2007. 


\section{ANALIZA KOMFORTU JAZDY PASAŻERA WYBRANYCH TYPÓW POJAZDÓW SZYNOWYCH}

\section{Wstęp}

Wraz z rozwojem transportu wzrastają również oczekiwania konsumentów usług transportowych. Wymagania pasażerów dotyczą coraz lepszej dostępności środków transportu w czasie, samego czasu przejazdu oraz poprawy warunków odbywanej podróży. Komfort jazdy staje się więc czynnikiem, który jest istotny w kontekście konkurencyjności poszczególnych gałęzi transportu [3]. Poziom komfortu może więc determinować wybory klientów. Zapewnienie pozytywnych odczuć związanych z komfortem nie powinno być powodowane jedynie chęcią sprostania rosnącym wymaganiom pasażerów. Odpowiedni poziom komfortu jazdy ma bowiem wpływ na zdrowie pasażerów oraz ich bezpieczeństwo, szczególnie w przypadku podróży na dłuższych dystansach. Praca ta ma na celu zidentyfikowanie najważniejszych czynników warunkujących komfort jazdy oraz analizę jego poziomu w wybranych pojazdach szynowych z punktu widzenia pasażera.

\section{Komfort jazdy w środkach transportu}

Komfort jazdy to pojęcie złożone, na które wpływa wiele czynników. Pojęciem tym określa się stan satysfakcji psychofizycznej pasażera danego pojazdu. Komfort jazdy pasażera oznacza więc ogół wszystkich warunków zewnętrznych, zapewniających poczucie przede wszystkim bezpieczeństwa, ale też wygody i zadowolenia podczas podróży [17, 18]. Występowanie wszelkich negatywnych bodźców może przyczyniać się do znacznego obniżenia odczuwanego poziomu komfortu. Długotrwałe lub intensywnie oddziałujące na pasażera niedogodności skutkują wystąpieniem przeciwnego stanu, jakim jest dyskomfort.

Odczucia pasażera związane $\mathrm{z}$ komfortem jazdy są determinowane przez szereg czynników związanych ze środowiskiem, w jakim podróżuje pasażer oraz jego cech indywidualnych $[6,8,18]$. Do bodźców wpływających na poziom komfortu należy zaliczyć takie elementy przestrzeni jak: rozkład przedziału pasażerskiego, ilość miejsca na nogi, odległość pomiędzy siedzeniami. W tej grupie czynników uwzględniane są również parametry fotela pozwalające na zajęcie ergonomicznej pozycji. Znaczenie mają więc kształt fotela, jego profil i wysokość, rozmieszenie podłokietników i zagłówków oraz możliwość regulacji kąta pochylenia oparcia. Kolejnym czynnikiem związanym z przestrzenią jest kolorystyka wnętrza pojazdu [18]. Zaleca się stosowanie neutralnych 
i stonowanych barw wewnątrz przedziałów, tak aby zachować odpowiedni kontrast, zmniejszać odblaski oraz móc zapewnić dobre oświetlenie [1]. W przypadku czynników czasoprzestrzennych, które mogą wpływać na obniżenie odczuwanego poziomu komfortu należy wymienić też stopień zapełnienia i czystość pojazdu oraz czas przejazdu i ewentualne opóźnienia [2, 8, 17].

Poziom komfortu jazdy w znacznym stopniu uzależniony jest też od takich czynników środowiskowych jak hałas, drgania, oświetlenie oraz temperatura powietrza, jego wilgotność i cyrkulacja oraz to jak długo pasażer jest eksponowany na poszczególne bodźce. Istotne jest więc utrzymanie odpowiednich warunków mikroklimatycznych i zapewnienie komfortu termicznego poprzez sprawną wentylację i klimatyzację. W optymalnych warunkach cieplnych pasażer odczuwa temperaturę równomiernie, a żadna część jego ciała nie jest nadmiernie chłodzona lub o przegrzewana [5]. W literaturze przedmiotu można odnaleźć wytyczne dotyczące oświetlenia zapewniającego pozytywne odczucia komfortu wizualnego, przy czym największe znaczenie ma natężenie i równomierność oświetlenia oraz jego temperatura barwowa $[1,18]$. W celu zapewnienia komfortu akustycznego istotne jest ograniczanie wszelkich niepożądanych, nieprzyjemnych, dokuczliwych czy wręcz szkodliwych dźwięków. Parametrami hałasu, które mają największe znaczenie w badaniach komfortu jazdy, są natężenie i częstotliwość dźwięku oraz występowanie składowych niesłyszalnych hałasu. Znaczenie ma też charakter bodźców akustycznych, w tym to czy pasażer jest narażony na hałas o charakterze ciągłym lub na impulsywne, jednorazowe dźwięki oraz jak długo jest on eksponowany na hałas. W grupie czynników środowiskowych, które determinują odczucia związane z komfortem najważniejszym i najczęściej badanym czynnikiem są drgania [4, 8-13, 17, 18]. Podczas jazdy pojazd szynowy wykonuje ruch postępowy oraz ruchy wibracyjne. Drgania oddziałujące na pasażera mogą skutkować wystąpieniem skutków funkcjonalnych lub fizjologicznych w zależności od czasu ich występowania $[14,15]$. Najważniejszymi parametrami drgań uwzględnianymi w analizie ich wpływu na komfort jazdy są amplituda przyspieszenia i ich częstotliwość [8, 18]. Odczucia związane z komfortem wibracyjnym zależą też od miejsca przyłożenia drgań do ciała człowieka oraz kierunkiem ich propagacji.

Oprócz czynników, które określają otoczenie pasażera, należy również wymienić te, które zależą wyłącznie od indywidualnych cech człowieka. Na negatywne bądź pozytywne odczucia związane z komfortem jazdy mogą wpływać waga, wzrost, budowa ciała, kondycja fizyczna i psychiczna, stan zdrowia czy też płeć i wiek pasażera. Wrażenie komfortu może różnić się pomiędzy poszczególnymi pasażerami ze względu na postawę ciała, indywidualną dynamiczną odpowiedź ciała, a nawet osobiste oczekiwania i nastawienie psychiczne pasażera.

\section{Metody oceny komfortu jazdy}

Analizę komfortu jazdy pasażera pojazdu szynowego można oprzeć na różnych wskaźnikach wyznaczanych na podstawie wielkości fizycznych, które charakteryzują 
otoczenie. W niniejszej pracy badania skupiono na głównym czynniku determinującym odczucia związane z komfortem, czyli na drganiach mechanicznych. Do analizy komfortu wykorzystano dwie metody związane z drganiami. Pierwszą z nich byłą metoda spektralna zgodna z zaleceniami normy ISO 2631-1:1985 [7], która pozwala na ocenę wpływu drgań ogólnych na ciało człowieka. Wielkością opisującą drgania, na której została oparta analiza, były wartości skuteczne w pasmach tercjowych, mierzone w trzech kierunkach. Drugą metodą oceny wpływu drgań na odczucia związane z komfortem była metoda ważona zgodna z wydaniem tej samej normy z 1997 r., gdzie wprowadzono zalecenia wyznaczania syntetycznego wskaźnika komfortu również na podstawie wartości RMS.

\subsection{Metoda spektralna}

Analiza komfortu jazdy metodą spektralną wymaga przeprowadzenia pomiarów przyspieszeń drgań w trzech kierunkach: poprzecznym, wzdłużnym oraz pionowym. Na podstawie eksperymentalnych wyników przyspieszeń w dziedzinie czasu należy wyznaczyć ich wartości skuteczne w pasmach tercjowych o częstotliwościach środkowych z zakresu od $0,8 \mathrm{~Hz}$ do $80 \mathrm{~Hz}$. Następnie wartości skuteczne są porównywane z granicami komfortu, uciążliwości i szkodliwości. W normie ISO 2631-1:1985 granice zdefiniowano oddzielnie dla drgań oddziałujących w kierunku wzdłużnym oraz poprzecznym i oddzielnie dla drgań pionowych.
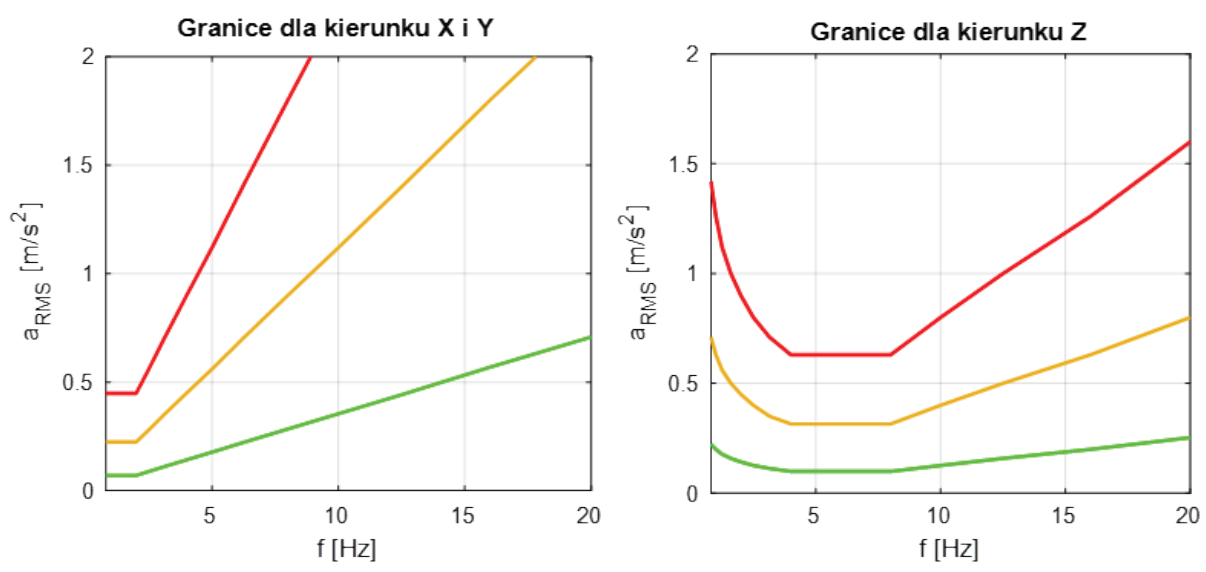

Rys. 1. Granice komfortu (linia zielona), uciążliwości (linia pomarańczowa) oraz granica szkodliwości (linia czerwona) zgodna z normą ISO 2631-1:1985 [7]

\subsection{Metoda ważona}

W metodzie ważonej należy wyznaczyć wskaźnik komfortu jazdy, który w normie ISO 2631-1:1997 wyrażony jest przez całkowite ważone przyspieszenie skuteczne [7]. Analogicznie jak w metodzie spektralnej podstawą analizy komfortu wibracyjnego są 
wartości skuteczne przyspieszeń drgań w pasmach tercjowych. Wartości RMS należy uśrednić z wykorzystaniem wag zdefiniowanych w normie [7]. Funkcję wagową $\mathrm{W}_{\mathrm{d}}(\mathrm{f})$ należy stosować dla drgań w kierunku wzdłużnym i poprzecznym, a funkcję $\mathrm{W}_{\mathrm{k}}(\mathrm{f})$ do drgań w kierunku pionowym.

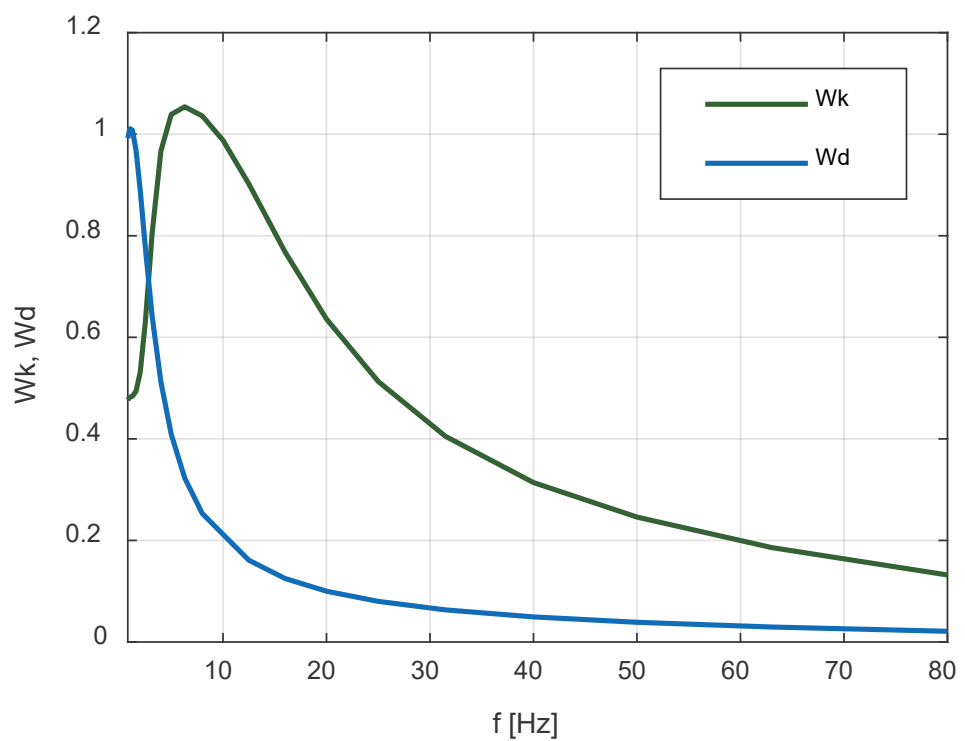

Rys. 2. Funkcje wagowe $\mathrm{W}_{\mathrm{k}}$ i $\mathrm{W}_{\mathrm{d}}$ stosowane w metodzie ważonej zgodnej z normą 2631-1:1997 [7]

Do obliczenia składowych ważonych przyspieszeń skutecznych wykorzystywane są wzory (1)-(3):

$$
a_{x, r m s-w a \grave{z}}=\sqrt{\sum_{i=1}^{n}\left[W_{d}\left(f_{i}\right) a_{x, r m s}\left(f_{i}\right)\right]^{2}}
$$

gdzie:

$\mathrm{W}_{\mathrm{d}}\left(\mathrm{f}_{\mathrm{i}}\right)$ - wartość funkcji wagowej $\mathrm{w} i$-tym pasmie tercjowym, $\mathrm{a}_{\mathrm{x}}$, rms $\left(\mathrm{f}_{\mathrm{i}}\right)$ - wartość skuteczna przyspieszenia w kierunku X w $i$-tym pasmie tercjowym, $\mathrm{a}_{\mathrm{x}, \text { rms -waż }}$ - uśredniona ważona wartość RMS dla kierunku X.

$$
a_{y, r m s-w a \dot{z}}=\sqrt{\sum_{i=1}^{n}\left[W_{d}\left(f_{i}\right) a_{y, r m s}\left(f_{i}\right)\right]^{2}}
$$

gdzie:

$\mathrm{W}_{\mathrm{d}}\left(\mathrm{f}_{\mathrm{i}}\right)$ - wartość funkcji wagowej $\mathrm{w} i$-tym pasmie tercjowym,

$\mathrm{a}_{\mathrm{y}}$, rms $\left(\mathrm{f}_{\mathrm{i}}\right)$ - wartość skuteczna przyspieszenia w kierunku Y w $i$-tym pasmie tercjowym,

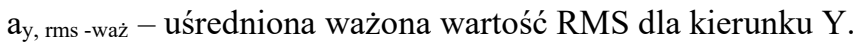

$$
a_{z, r m s-w a \dot{z}}=\sqrt{\sum_{i=1}^{n}\left[W_{k}\left(f_{i}\right) a_{z, r m s}\left(f_{i}\right)\right]^{2}}
$$


gdzie:

$\mathrm{W}_{\mathrm{k}}\left(\mathrm{f}_{\mathrm{i}}\right) \quad$ - wartość funkcji wagowej w $i$-tym pasmie tercjowym,

$\mathrm{a}_{\mathrm{z}, \mathrm{rms}}\left(\mathrm{f}_{\mathrm{i}}\right)$ - wartość skuteczna przyspieszenia w kierunku $\mathrm{Z}$ w $i$-tym pasmie tercjowym,

a , rms -waż - uśredniona ważona wartość RMS dla kierunku Z.

Na podstawie składowych wartości ważonych przyspieszeń wyznaczany jest wskaźnik komfortu jazdy na podstawie wzoru (4):

$$
a_{r m s-w a \dot{z}}=\sqrt{a_{x, r m s-w a \dot{z}}^{2}+a_{y, r m s-w a \dot{z}}^{2}+a_{z, r m s-w a \dot{z}}^{2}}
$$

gdzie:

$\mathrm{a}_{\text {rms-waż }}$ - wskaźnik komfortu wyrażony przez całkowite ważone przyspieszenie skuteczne.

Obliczony wskaźnik komfortu należy porównać z opisową skalą komfortu zamieszczoną w tab. 1.

Tabela 1

Skala komfortu zgodna z normą ISO 2631-1:1997 [7]

\begin{tabular}{|l|l|}
\hline \multicolumn{1}{|c|}{$a_{r m s-w a z ̇}\left[\mathrm{~m} / \mathrm{s}^{2}\right]$} & \multicolumn{1}{|c|}{ Poziom komfortu } \\
\hline poniżej 0,315 & komfortowo \\
\hline Od 0,315 do 0,630 & nieznacznie niekomfortowo \\
\hline od 0,500 do 1,000 & dość niekomfortowo \\
\hline od 0,800 do 1,600 & niekomfortowo \\
\hline od 1,250 do 2,500 & bardzo niekomfortowo \\
\hline powyżej 2,000 & ekstremalnie niekomfortowo \\
\hline
\end{tabular}

\section{Komfort jazdy w pojazdach szynowych - badania doświadczalne}

\subsection{Pomiary przyspieszeń drgań}

Analiza komfortu jazdy dotyczyła czterech typów pojazdów szynowych: w tramwaju $120 \mathrm{Na}$ Swing, elektrycznym zespole trakcyjnym 27WE Elf, pociągu metra Siemens Inspiro oraz pociągu pasażerskiego zestawionego $\mathrm{z}$ wagonów $\mathrm{z}$ przedziałami typu $\mathrm{Z} 1 \mathrm{~B}$ i lokomotywy spalinowej Pesa Gama. W każdym z tych pojazdów obrano po jednym punkcie pomiarowym, w którym rejestrowano przyspieszenia drgań jednocześnie w trzech kierunkach. Wszystkie pomiary przeprowadzono podczas typowej jazdy z pasażerami, 
uwzględniając takie warunki jak: hamowanie, jazda jednostajna, przejazd przez rozjazdy. Do pomiarów przyspieszeń drgań wykorzystano aparaturę pomiarową w postaci akcelerometru trójosiowego siedziskowego oraz karty przetwornikowej. Pomiary rejestrowane były na komputerze przenośnym z programem w środowisku LabView. W wyniku eksperymentu badawczego otrzymano przebiegi przyspieszeń drgań w czasie. Przykład jednego z wyników pomiarów został zobrazowany na rys. 3 dla pomiaru zarejestrowanego w pociągu metra.
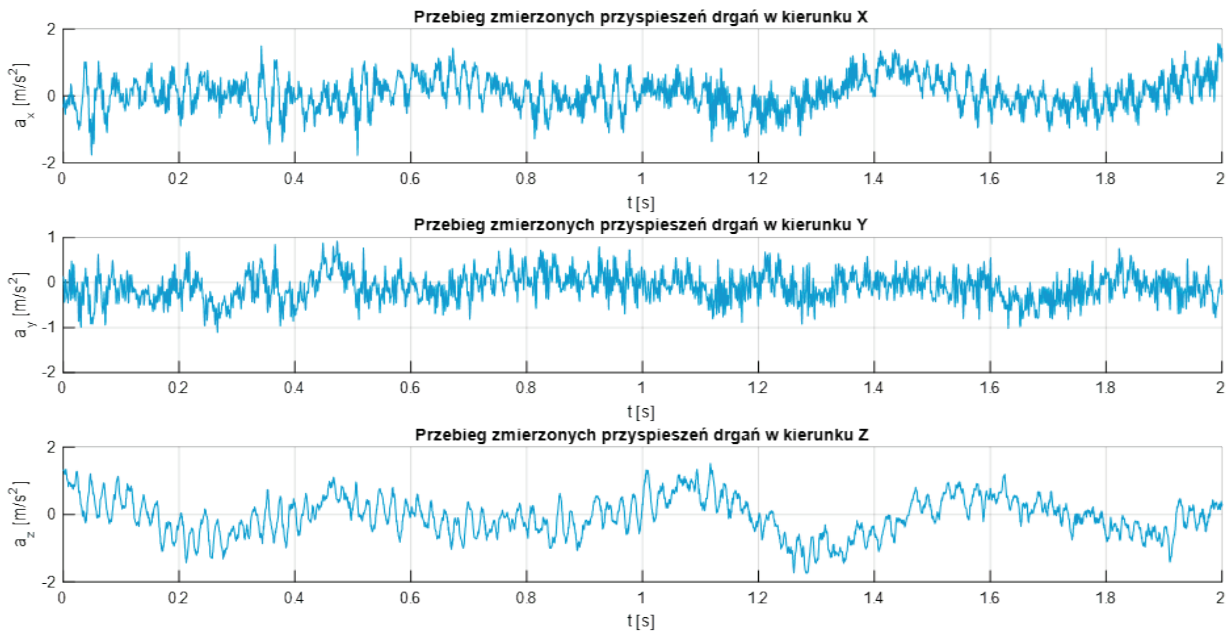

Rys. 3. Przyspieszenia drgań dla wybranego pomiaru zarejestrowanego w pociągu metra Siemens Inspiro

\subsection{Analiza komfortu jazdy - metoda spektralna}

Na podstawie wybranych wyników badań eksperymentalnych obliczono wartości skuteczne przyspieszeń drgań $\mathrm{w}$ pasmach tercjowych dla każdego $\mathrm{z}$ badanych typów pojazdów szynowych. Na rysunkach 4-7 zamieszczono wyniki RMS wraz z granicami komfortu zgodnymi z normą [7]. 
a)

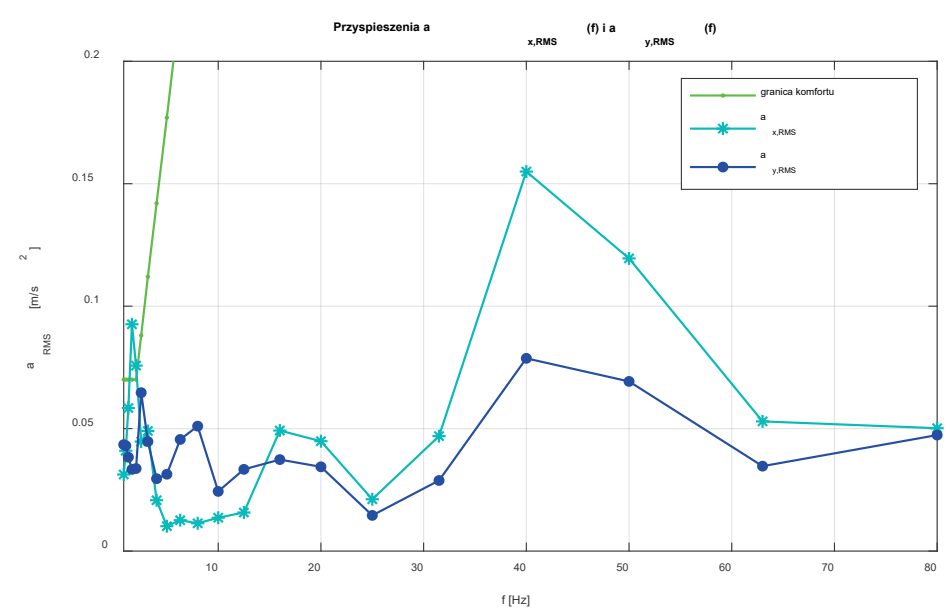

b)

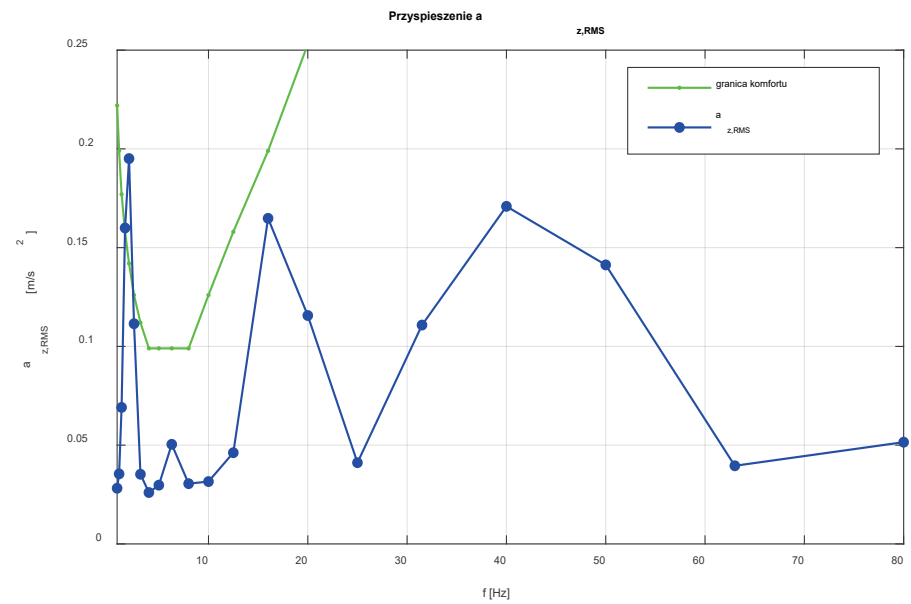

Rys. 4. Wartości skuteczne przyspieszeń drgań zmierzonych w pociągu metra Siemens Inspiro, w kierunku wzdłużnym i poprzecznym (a) oraz w kierunku pionowym (b), porównane $\mathrm{z}$ granicą komfortu

Z wykresów dla pociągu metra Siemens Inspiro zamieszczonych na rys. 4 wynika, iż granica komfortu została przekroczona tylko w przypadku drgań o niskich częstotliwościach oddziałujących w kierunku wzdłużnym. Wyniki RMS dla drgań poprzecznych nie przekraczają granicy komfortu. Można więc uznać, że drgania w tym kierunku nie powodowały negatywnych odczuć związanych z komfortem wibracyjnym. Podobnie jak w przypadku drgań w kierunku wzdłużnym drgania pionowe przekroczyły granicę komfortu dla RMS w pasmach o niskich częstotliwościach. Przy częstotliwościach $16 \mathrm{~Hz}$ i $40 \mathrm{~Hz}$ zauważalny jest kolejny wzrost wartości skutecznych drgań pionowych, natomiast nie można uznać, by wartości te obniżały poziom komfortu odczuwanego przez pasażera pociągu metra - granica komfortu nie została przekroczona. 
a)

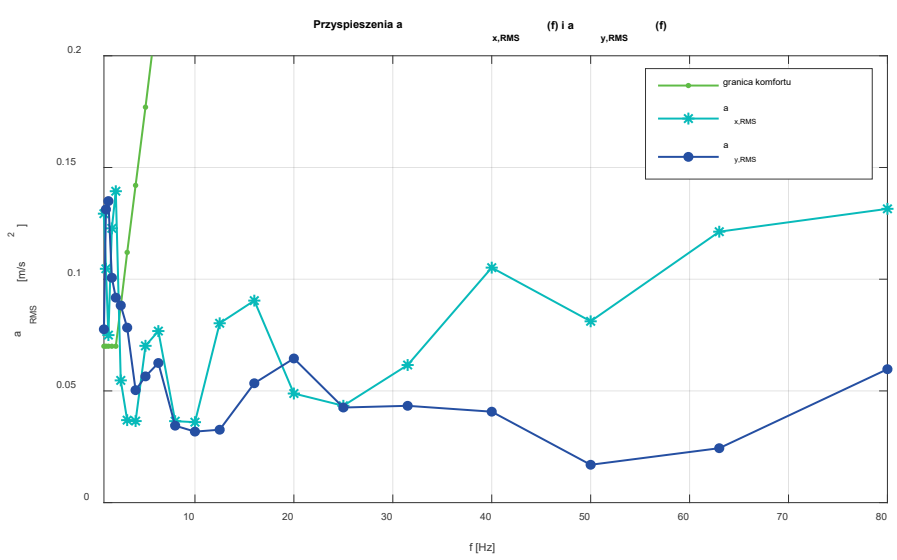

b)

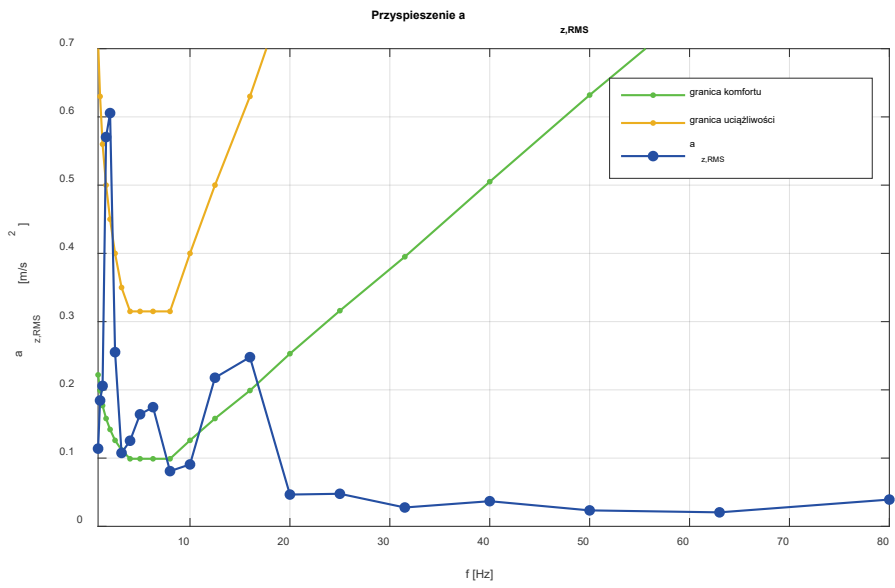

Rys. 5. Wartości skuteczne przyspieszeń drgań zmierzonych w tramwaju $120 \mathrm{Na}$ Swing, w kierunku wzdłużnym i poprzecznym (a) oraz w kierunku pionowym (b), porównane z granicami komfortu i uciążliwości

Analizując wykresy wartości RMS dla tramwaju 120Na Swing (rys. 5), można zauważyć, iż granica komfortu została przekroczona w przypadku drgań oddziałujących na pasażera w każdym z trzech kierunków. Większość przypadków przekroczenia tej granicy obserwowana była dla drgań o niewielkich częstotliwościach. Szczególną uwagę należy zwrócić na wartości RMS drgań pionowych. Dla niskich częstotliwości z zakresu 1,6-2 Hz ma bowiem miejsce nie tylko przekroczenie granicy komfortu, ale także granicy uciążliwości. W odróżnieniu od pozostałych kierunków propagacji drgań, granica komfortu została przekroczona w przypadku drgań pionowych też dla większych częstotliwości. Największy wpływ na negatywne odczucia związane z komfortem jazdy mają więc drgania pionowe. 
a)

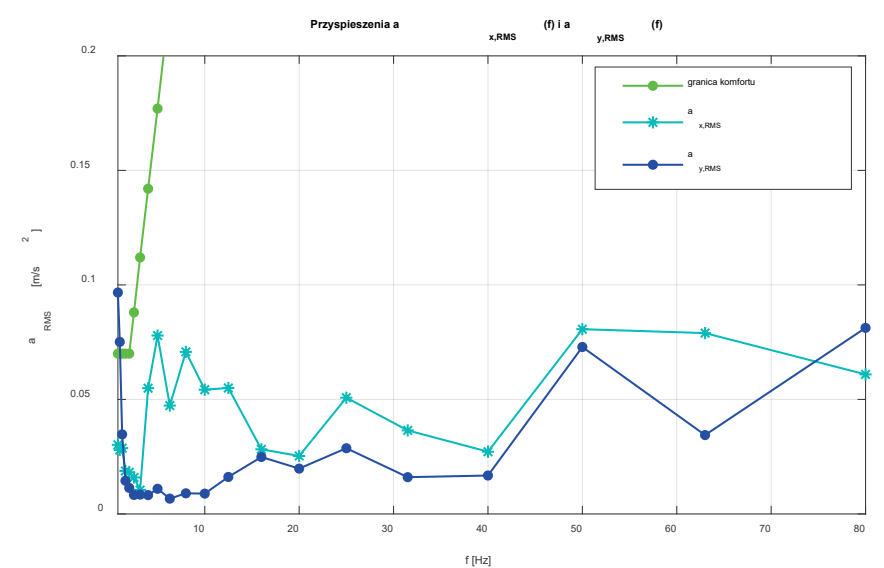

b)

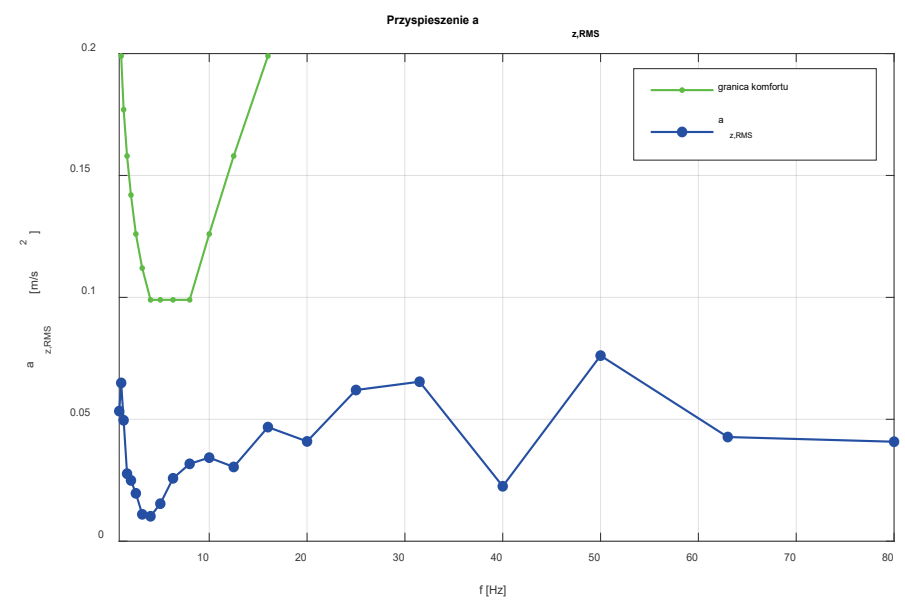

Rys. 6. Wartości skuteczne przyspieszeń drgań zmierzonych w EZT 27WE Elf, w kierunku wzdłużnym i poprzecznym (a) oraz w kierunku pionowym (b), porównane z granicami komfortu i uciążliwości

W przypadku wyników RMS dla pojazdu 27WE Elf (rys. 6) zauważalne jest nieznaczne przekroczenie granicy komfortu tylko przez drgania oddziałujące na pasażera w kierunku poprzecznym. Przekroczenie granicy miało miejsce dla częstotliwości poniżej $2 \mathrm{~Hz}$. Wartości skuteczne przyspieszeń drgań wzdłużnych i pionowych były na tyle niewielkie, że nie można uznać, iż wpływały negatywnie na odczucia związane z komfortem jazdy. W związku z nieznacznym przekroczeniem granicy komfortu tylko przez drgania poprzeczne można uznać, że podróż elektrycznym zespołem trakcyjnym 27WE Elf jest dość komfortowa. 
a)

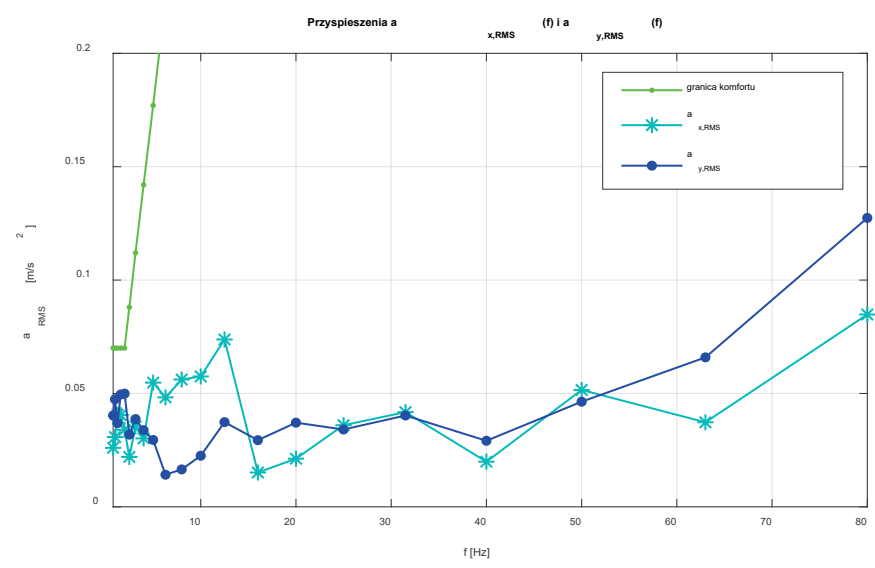

b)

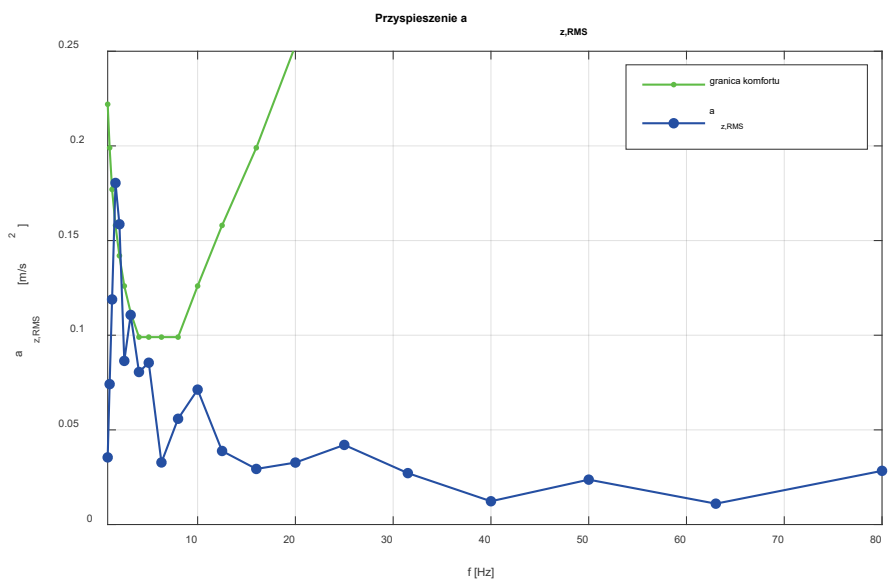

Rys. 7. Wartości skuteczne przyspieszeń drgań zmierzonych w pociągu pasażerskim, w kierunku wzdłużnym i poprzecznym (a) oraz w kierunku pionowym (b), porównane z granicą komfortu

Zgodnie z wynikami przedstawionymi na rys. 7 wartości RMS drgań wzdłużnych i poprzecznych w badanym pociągu pasażerskim nie przekraczają granicy komfortu. Dla częstotliwości środkowej pasma równej $80 \mathrm{~Hz}$ zauważalny jest znaczny wzrost wartości skutecznych tych przyspieszeń. Wzrost ten nie przyczynił się jednak do obniżenia poziomu odczuwanego przez pasażera komfortu jazdy, gdyż wartości RMS nie przekroczyły wartości granicznych. W części b rys. 7 zamieszczone zostały wyniki dla drgań pionowych. Podobnie jak w przypadku wyników dla poprzednich pojazdów granica komfortu została przekroczona przez drgania o niskich częstotliwościach. Analizując wykres, można zauważyć, że dla pozostałych częstotliwości otrzymane wartości RMS są stosunkowo niewielkie, a więc nie wpływają negatywnie na odczucia związane $\mathrm{z}$ komfortem wibracyjnym. 


\subsection{Ocena komfortu jazdy przy użyciu metody ważonej}

W drugim etapie analizy komfortu jazdy pasażera czterech typów pojazdów szynowych wykorzystana została metoda ważona. Na podstawie wcześniej wyznaczonych wartości skutecznych przyspieszeń drgań oraz z wykorzystaniem wzorów (1)-(4) i funkcji wagowych obliczone zostały wskaźniki komfortu jazdy zgodnie z normą [7]. Wyniki składowych ważonych przyspieszeń skutecznych oraz wskaźników komfortu wraz z odpowiadającym im poziomem komfortu zamieszczone zostały w tab. 2.

Tabela 2

Ważone wartości skuteczne składowych przyspieszenia drgań i wskaźnik komfortu dla badanych pojazdów szynowych

\begin{tabular}{|c|c|c|c|c|c|}
\hline $\begin{array}{c}\text { Pojazd } \\
\text { szynowy }\end{array}$ & ax,RMS -waż & $\mathbf{a}_{\mathbf{y}, \text { RMS-waż }}$ & az,RMS-waż & acalk,RMS-waż & $\begin{array}{c}\text { Poziom } \\
\text { komfortu }\end{array}$ \\
\hline Metro & 0,146 & 0,107 & 0,246 & 0,305 & Komfortowo \\
\hline Tramwaj & 0,260 & 0,259 & 0,638 & 0,736 & $\begin{array}{c}\text { Dość } \\
\text { niekomfortowo }\end{array}$ \\
\hline Pesa Elf & 0,077 & 0,129 & 0,105 & 0,183 & Komfortowo \\
\hline $\begin{array}{c}\text { Pociąg } \\
\text { pasażerski }\end{array}$ & 0,090 & 0,107 & 0,239 & 0,277 & Komfortowo \\
\hline
\end{tabular}

Porównując otrzymaną dla pojazdu metra Simens Inspiro wartość wskaźnika ze skalą komfortu, można uznać, że drgania nie wpłynęły negatywnie na odczucia poziomu komfortu. Podobne wyniki zaobserwowano dla pociągu pasażerskiego, gdzie wskaźnik komfortu osiągnął niewiele mniejszą wartość. W przypadku elektrycznego zespołu trakcyjnego Elf obliczony wskaźnik był najniższy, zatem jazdę tym pojazdem można uznać za najbardziej komfortową spośród wszystkich analizowanych środków transportu. Najwyższy wynik odnotowano dla tramwaju Swing. Wartość wskaźnika zawiera się w przedziale od 0,5 do $0,1 \mathrm{~m} / \mathrm{s}^{2}$. Zgodnie ze skalą jazdę tym pojazdem należy uznać za dość niekomfortową. Co istotne, wartość wskaźnika była bliska osiągnięcia kolejnego poziomu w skali, przy którym jazda określana jest jako niekomfortowa.

\section{Wnioski}

W badaniach komfortu jazdy pasażera pojazdu szynowego wykorzystane zostały dwie metody oparte na pomiarach przyspieszeń drgań mechanicznych. Analiza tych przyspieszeń metodą spektralną i metodą ważoną umożliwiła ocenę wpływu wibracji w badanych pojazdach na odczucia związane z komfortem. Poniżej zamieszczono najważniejsze wnioski z przeprowadzonych badań: 
- największy komfort jazdy zapewnia podróż pojazdem 27WE Elf (najmniejsza wartość wskaźnika komfortu), natomiast najgorsze odczucia związane z komfortem wibracyjnym doświadczają pasażerowie tramwaju $120 \mathrm{Na}$ Swing (wysoka wartość wskaźnika);

- tylko w przypadku tramwaju, wartości RMS przekroczyły granicę komfortu we wszystkich kierunkach oddziaływania drgań, dodatkowo przyspieszenia drgań pionowych o niskich częstotliwościach przekroczyły też granicę uciążliwości;

- większość przypadków przekroczenia granicy komfortu miała miejsce dla drgań oddziałujących w kierunku pionowym, były to drgania o niskich częstotliwościach.

Wyniki badań eksperymentalnych wykazały, iż do obniżenia komfortu jazdy najbardziej przyczyniają się drgania o niskich częstotliwościach. Na tak oddziałujące na pasażera wibracje należy zwrócić szczególną uwagę ze względu na możliwość wystąpienia zjawiska rezonansu dla drgań narządów wewnętrznych. W związku ze złożonością zagadnienia, jakim jest komfort jazdy oraz różnicami w percepcji bodźców oddziałujących na człowieka, wskazane jest zwiększenie zakresu badań. Analizę komfortu jazdy można więc rozszerzyć o komfort akustyczny, termiczny czy wizualny oraz o badania ankietowe określające subiektywne odczucie komfortu.

\section{Literatura}

1. Chrzanowicz, M.: Wymagania normalizacyjne dotyczące oświetlenia elektrycznego pojazdów szynowych w systemach transportu publicznego (PN-EN 13272: 2012) oraz analiza wybranych systemów oświetleniowych. Logistyka nr 4, CD 2/2014.

2. Ciastoń-Ciulkin A.: Analiza poziomu komfortu podróży w pociągach aglomeracyjnych na trasie Kraków Lotnisko/Airport-Wieliczka Rynek Kopalnia. Transport Miejski i Regionalny, nr 6/2017.

3. Dyr T.: Konkurencyjność transportu kolejowego na rynku regionalnych przewozów pasażerskich. TTS Technika Transportu Szynowego, nr 1-2/2004.

4. Förstberg J.: Ride comfort and motion sickness in tilting trains. Doctoral Thesis, Instituten för farkosttenknik, Stokholm 2000.

5. Gużda A., Szmolke N.: Przykłady rozkładu parametrów powietrza w autobusie komunikacji miejskiej. Autobusy: technika, eksploatacja, systemy transportowe, nr $6 / 2016$.

6. Gołębiowski P., Żak J., Jacyna-Gołda I.: Approach to the Proecological Distribution of the Traffic Flow on the Transport Network from the Point of View of Carbon Dioxide. Sustainability 12.17 (2020): 6936.

7. ISO 2631-1: Mechanical Vibration and Shock. Evaluation of human exposure wholebody vibration. Part 1: General Requirements. Internationa Organization for Standardization, 1985 i 1997. 
8. Kardas-Cinal E.: Bezpieczeństwo i komfort jazdy pojazdu szynowego z uwzględnieniem losowych nierówności geometrycznych toru, nr 94, Oficyna Wydawnicza Politechniki Warszawskiej, Warszawa 2013.

9. Kardas-Cinal E.: Metody oceny komfortu wibracyjnego w środkach transportu. Prace Naukowe Politechniki Warszawskiej, Transport, z. 112, 2016.

10. Kardas-Cinal E.: Statistical analysis of dynamical quantities relate to running safety and ride comfort of a railway vehicle. Zeszyty Naukowe. Transport - Politechnika Śląska, t. 106, 2020.

11. Krakasis K., Skarlatos D., Zakinthios T.: A factorial analysis for the determination optimal train speed with desired ride comfort. Tilemachos Applied Acoustics, Vol. 66(10), 2005.

12. Król S.: Przegląd metod oceny wibracyjnego komfortu jazdy w pojazdach szynowych. Transport Miejski i Regionalny, nr 3/2009.

13. Król S., Szczygieł J.: Badania poziomu komfortu wibracyjnego w wybranych tramwajach. Problemy eksploatacji, nr 2/2009.

14. Nader M.: Drgania i hałas w transporcie: wybrane zagadnienia. Oficyna Wydawnicza Politechniki Warszawskiej, Warszawa 2016.

15. Nader M., Ilczuk P., Korzeb J.: Oddziaływanie drgań na kierowcę pojazdu podczas niestandardowej eksploatacji. Logistyka 4, 2015.

16. PN-EN 13272-1:2020-03 Kolejnictwo - Oświetlenie elektryczne pojazdów szynowych w systemach transportu publicznego - Część 1: Kolej, PKN, 2020.

17. Rybicka I., Tarkowski S.: Metody oceny poziomu komfortu dynamicznego w transporcie pasażerskim. Autobusy: technika, eksploatacja, systemy transportowe, nr $12 / 2016$.

18. Šipic P.: Komfort jazdy w pasażerskim transporcie szynowym. Technika Transportu Szynowego, nr 7-8/2007. 